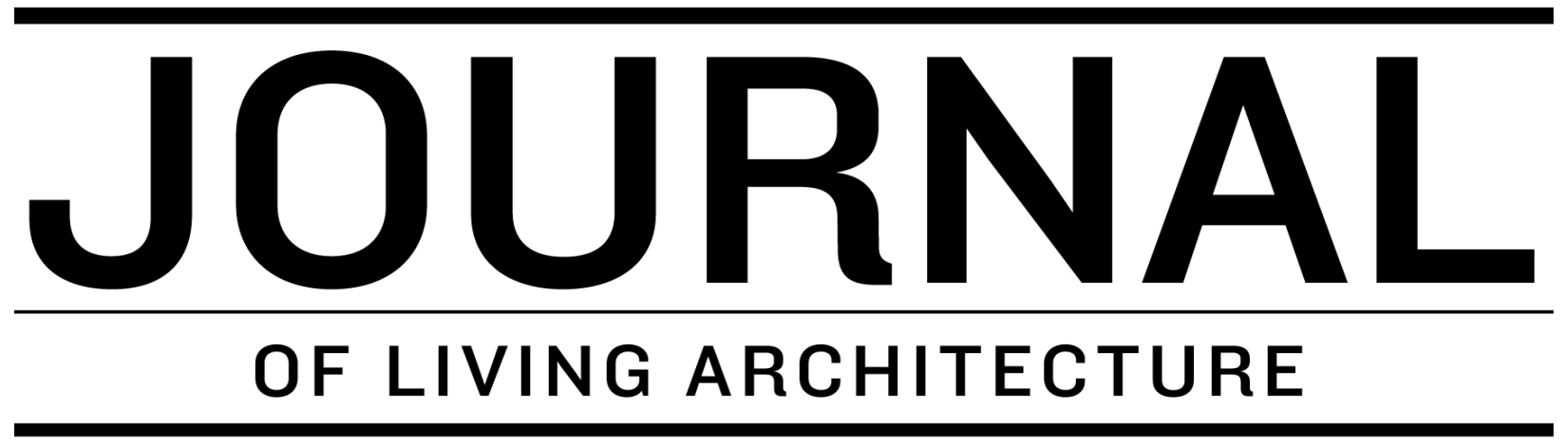

A GREEN ROOFS FOR HEALTHY CITIES PUBLICATION

\title{
Insect Communities on Green Roofs that are Close in Proximity but Vary in Age and Plant Coverage
}

Anthony Steck

Department of Biological Sciences, Southern Illinois University, Edwardsville IL, 62026

Susan Morgan

Department of Civil Engineering, School of Engineering, Southern Illinois University,

Edwardsville IL, 62026

William Retzlaff

College of Arts and Sciences, Southern Illinois University, Edwardsville IL, 62026

Jason Williams*

Department of Biological Sciences, Southern Illinois University, Edwardsville IL, 62026, jasowil@siue.edu Phone: 618-650-2118FAX: (618)650-3174

\begin{abstract}
The effects of roof age and plant coverage on insect communities were investigated between three green roofs located on the campus of Southern Illinois University Edwardsville. Insect collections were made using pitfall traps on green roofs that were established between 0.5 month and five years prior to insect collection. The green roof with the greatest insect collection rate was the oldest but intermediate in size and percent plant coverage. The oldest green roof had similar collection rates as a nearby ground-level rain garden; however measures of species diversity and evenness were greater in the rain garden.
\end{abstract}

Keywords: Green roof, rain garden, insect diversity, pitfall trap

Please Cite as: Steck, A., S. Morgan, W. Retzlaff, J.B. Williams., 2015. Insect communities on green roofs that are close in proximity but vary in age and plant coverage. Journal of Living Architecture. 2(1): 1-11. Available at http://greenroofs.org/resources/JOLA2015.2.1.Steck.pdf

This peer-reviewed Article is provided free and open-access. 


\section{INTRODUCTION}

Lack of green space in urban areas can have profound environmental and social impacts, such as increased thermal extremes, reduced carbon absorption, disturbed water quality and biodiversity, and negative impact to multiple facets of human health (Jo 2002; Jackson 2003). Traditionally, parks, gardens, and open spaces have been used to help alleviate such problems. Recently, however, green structures have been frequently used as a potential remedy for these problems because they can greatly increase green space in existing developed areas. Green structures, such as green roofs or walls, are classified accordingly because plants are integrated within their assemblies and, thus, may partially replace the vegetative footprint that was destroyed by the construction of the building (Getter and Rowe 2006).

In addition to the many quality of life and energy saving benefits, such as reducing storm water runoff, mitigating the urban heat island effect, easing air pollution, increasing energy conservation, and providing a visually pleasing environment while reducing noise pollution (see references in Getter and Rowe 2006; Susca et al. 2011; Yang et al. 2012; Sutton 2014), green roofs may also provide ecological services lost through urbanization. For instance, green roofs have been demonstrated to be habitat for native plants (Dewey et al. 2004) and a variety of animals, particularly birds (Grant 2006, Brenneissen 2003) and invertebrates. Kadas (2006) estimated that over $10 \%$ of beetles collected on several green roofs in London were categorized as nationally rare or scarce. Similarly, a study comparing green roof to ground level invertebrate fauna found unique communities existed on the roofs (Gedge and Kadas 2005), suggesting green roofs may be important tools to increase insect diversity in urban areas. However others determined invertebrates on green roofs were comprised of only a subset of communities that existed at ground level (MacIvor and Lundholm 2011; Tonietto et al. 2011).

Parameters of green roofs that may influence insect diversity are numerous. Previous studies indicated that vegetation diversity and amount of vegetation cover were correlated to arthropod diversity, while other parameters, such as green roof area, height, and distance to ground-level vegetative, were not correlated to diversity (Gedge and Kadas 2005; Schindler et al. 2011; Madre et al. 2013). In addition, age of green roof was positively correlated with soil formation and collembolan densities (Schrader and Böning 2006). However, most studies measuring insect diversity used green roofs that were widely separated within a given city or across a region, varied in distance to ground-level green space or varied by plant species diversity.

In this observational study, we attempted to minimize these potentially confounding effects by using pitfall traps to measure insect collection, species diversity, and evenness on three green roofs that were relatively close to one another (within $300 \mathrm{~m}$ ), had similar distances to ground-level green space and similar plant species diversity, but varied in size, percentage of ground cover and establishment age. To determine if green roof insect communities were similar to ground-level landscaping, we also sampled in a rain garden located near the green roofs. 


\section{METHODS AND MATERIALS}

\section{Collection areas}

Insects were collected from three extensive green roofs (Student Success Center, SSC: Rendleman Hall, RH; and Engineering Building, EB) and one ground plot on the campus of Southern Illinois University Edwardsville. All collection areas were relatively close to one another (within $300 \mathrm{~m}$ ) and had green space immediately surrounding them. In addition, heights of the green roofs were similar, ranging between 4.3 and 8.5 meters above finished grade.

The green roof on $\mathrm{RH}$ was the smallest $\left(22 \mathrm{~m}^{2}\right)$ and most recently planted (summer of 2010; Table 1). It contained 48 GreenGrid $^{\mathrm{TM}}$ green roof modules with a growth media blend containing arkalyte planted with Sedum sexangulare, Sedum acre, Sedum kamtschaticum, Sedum album, and Sedum spurium. The GreenGrid ${ }^{\mathrm{TM}}$ modules were surrounded by a $25 \mathrm{~cm}$ border of arkalyte aggregate $(2.5 \mathrm{~cm}$ cobble) and the entire green roof was surrounded with $60 \times 60 \mathrm{~cm}$ patio paving stones.

The green roof on top of the SSC was the largest at $1486 \mathrm{~m}^{2}$ and was planted in April 2009; a little over a year prior to the beginning of the study (Table 1). The growth media contained fine arkalyte (80\%) and composted pine bark (20\%) and was planted with Sedum sexangulare, Sedum reflexum, Sedum kamtschaticum, Sedum album, and Sedum spurium.

The EB contained two separate green roof sub-plots totaling $129 \mathrm{~m}^{2}$. The first sub-plot was planted in August of 2006 and is comprised of $75 \mathrm{~m}^{2}$ of GreenPaks green roof modules that are filled with a growth media blend of $80 \%$ lava and $20 \%$ composted pine bark and planted with Sedum spurium. The remainder of the green roof was planted in June of 2004 and is composed of $54 \mathrm{~m}^{2}$ of Green Roof Blocks containing Sedum sexangulare, Sedum reflexum, Sedum kamtschaticum, Sedum album, and Sedum spurium. The substrate in this area of green roof was comprised of four different inorganic components ( $80 \%$ lava, arkalyte, stalite, or pumice) and $20 \%$ composted pine bark. Effort in insect collection and estimation of ground cover was evenly split between the two green roofs on this building and all data was combined due to their immediate proximity to one another.

The rain garden $(\mathrm{RG})$ is a water retention area located to the north of the EB. Created in the summer of 2009, the $678 \mathrm{~m}^{2}$ area receives runoff from over $4047 \mathrm{~m}^{2}$ of paved parking surface. The substrate contains 15 inches of $30 \%$ compost, $24 \%$ soil, and $46 \%$ sand, topped with hardwood mulch. On September 15, 2009, 1190 plants, including native and non-native sedges, button bush, cardinal lobelia, goldenrod, aster, coneflower, blazing star, hydrangea, buckeye, viburnum, iris, little blue stem, and hibiscus were planted. In spring 2010, three bald cypress trees were also planted.

\section{Estimation of ground cover}

Total ground cover was determined using a modified dot grid that was 30 X $30 \mathrm{~cm}$ in size containing 36 open circles, each 3.8 centimeter in diameter. The grid was used between 50 and 55 times on each plot by placing the grid five equally spaced times along 10-11 randomly determined transects. Percent ground cover by plants was calculated by comparing the number 
of the 36 circles that were either covered (containing more than $50 \%$ plant surface when counted) to those that were bare (containing less than 50\% plant surface when counted) (Forrester 2006).

\section{Insect Collection}

Insects were collected using pitfall traps from August $13^{\text {th }}$ to October $1^{\text {st }} 2010$. Pitfall traps were chosen because they are effective at collecting surface active insects that may offer a more reliable index of long-term inhabitants of green roofs than other methods, such as aerial or light traps (Clark and Blom, 1992). The traps (266 ml polystyrene cups, measuring 8.5 centimeters at the mouth) were buried in the substrate with their rims flush with the ground and filled approximately two-thirds full with a 50-50 mixture of ethylene glycol and water. Four transects of five pitfall traps were randomly placed on the roofs and garden, except $\mathrm{RH}$, which, because of its small size, contained only two transects of five cups. Traps were placed two to three meters apart in a given transect. Trapped insects were removed weekly and stored in 70\% ethanol prior to pinning for identification. All traps in a single transect were pooled and a given transect was considered a separate replicate from others at a given study site. Any trap that was damaged or appeared disturbed was discarded and any insects it contained were not used for analysis.

Table 1. Planting date, months from planting until insect collection, and plot size for green roofs located on Rendlemen Hall (RH), the Student Success Center (SSC), and the Engineering Building (EB) as well as a ground level Rain Garden (RG) located at Southern Illinois University Edwardsville.

\begin{tabular}{ccccc}
\hline Measure & $\begin{array}{c}\text { Rendlemen } \\
\text { Hall }\end{array}$ & $\begin{array}{c}\text { Student } \\
\text { Success } \\
\text { Center }\end{array}$ & $\begin{array}{c}\text { Engineering } \\
\text { Building }\end{array}$ & Rain Garden \\
\hline Planting date & Aug. 2010 & April 2009 & $\begin{array}{c}\text { Aug. 2004/ } \\
\text { June 2006 }\end{array}$ & Sept. 2009 \\
$\begin{array}{c}\text { Months from planting } \\
\text { prior to insect } \\
\text { collection }\end{array}$ & 0.5 & 16 & $47-72$ & 11 \\
$\begin{array}{c}\left.\text { Plot size (m }{ }^{2}\right) \\
\text { Coordinates }\end{array}$ & 22 & 1486 & 129 & 678 \\
& $\begin{array}{l}38^{\circ} 47^{\prime} 32.8^{\prime \prime} \mathrm{N} \\
89^{\circ} 59^{\prime} 48.2^{\prime \prime} \mathrm{W}\end{array}$ & $\begin{array}{c}38^{\circ} 47^{\prime} 29.8^{\prime \prime} \mathrm{N} \\
89^{\circ} 59^{\prime} 53.2^{\prime \prime} \mathrm{W}\end{array}$ & $\begin{array}{c}38^{\circ} 47^{\prime} 31.7^{\prime \prime} \mathrm{N} \\
90^{\circ} 00^{\prime} 04.1^{\prime \prime} \mathrm{W}\end{array}$ & $\begin{array}{c}38^{\circ} 47^{\prime} 34.0^{\prime \prime} \mathrm{N} \\
90^{\circ} 00^{\prime} 05.1^{\prime \prime} \mathrm{W}\end{array}$ \\
\hline
\end{tabular}

\section{Faunal and statistical analysis}

All insects were identified to family using Bland and Jaques, 1974. The identified insects belonging to the most commonly represented orders (Orthoptera and Coleoptera) were identified to species using American Beetles, Vol. 1 by Arnett and Thomas (2000), American Beetles, Vol. 2 by Arnett et al. (2002) or The Orthoptera of Michigan by Bland (2003). We determined total number of insects, rate of insect collection (insects $\cdot \operatorname{trap}^{-1} \cdot$ day $^{-1}$ ), and species richness at each 
collection site for the entire trapping period. Calculations of species richness included a measure of species diversity (Shannon's diversity index H' utilizing a natural log base) and evenness (J) using species of Orthoptera and Coleoptera (Krebs 1989). Only a single species belonging to the orders Orthoptera or Coleoptera were collected on the RH and the SSC green roofs; thus, measures of species richness could not be calculated for these areas (Table 3).

Table 2. Total animals, orders, and scientific and common names of insect families collected on green roofs located on Rendlemen Hall (RH), the Student Success Center (SSC) and the Engineering Building (EB). For comparative purposes, insects were also collected in a ground level rain garden (RG) located in close proximity to the EB. All insects were collected using pitfall traps from August $13^{\text {th }}$ to October $1^{\text {st }}$ 2010.

\begin{tabular}{|c|c|c|c|c|c|}
\hline & $\mathrm{RH}$ & $\mathrm{SSC}$ & EB & RG & Total \\
\hline \multicolumn{6}{|l|}{ Order: Orthoptera } \\
\hline Family: Gryllidae (true crickets) & 5 & 0 & 257 & 103 & 364 \\
\hline Family: Tetrigidae (pygmy grasshoppers) & 0 & 0 & 0 & 3 & 3 \\
\hline Family: Acrididae (grasshoppers) & 0 & 7 & 1 & 8 & 16 \\
\hline \multicolumn{6}{|l|}{ Order: Coleoptera } \\
\hline Family: Carabidae (ground beetles) & 0 & 0 & 19 & 265 & 284 \\
\hline Family: Scarabaediae (scarab beetles) & 0 & 0 & 1 & 19 & 20 \\
\hline Family: Lampyridae (fireflies) & 0 & 0 & 0 & 1 & 1 \\
\hline \multicolumn{6}{|l|}{ Order: Hemiptera } \\
\hline Family: Lygaeidae (seed bugs) & 8 & 12 & 15 & 0 & 35 \\
\hline Family: Nabidae (damsel bugs) & 0 & 0 & 23 & 1 & 24 \\
\hline Family: Membracidae (treehoppers) & 0 & 0 & 0 & 1 & 1 \\
\hline \multicolumn{6}{|l|}{ Order: Hymenoptera } \\
\hline Family: Vespidae (yellow jackets and kin) & 0 & 1 & 0 & 0 & 1 \\
\hline Family: Formacidae (ants) & 0 & 1 & 1 & 8 & 10 \\
\hline Family: Pompilidae (spider wasps) & 0 & 0 & 1 & 0 & 1 \\
\hline Family: Argidae (sawflies) & 25 & 0 & 0 & 0 & 25 \\
\hline Family: Eumenidae (potter wasps) & 0 & 0 & 0 & 1 & 1 \\
\hline \multicolumn{6}{|l|}{ Order: Diptera } \\
\hline Family: Muscidae (house fly and kin) & 3 & 10 & 5 & 4 & 22 \\
\hline \multicolumn{6}{|l|}{ Order: Neuroptera } \\
\hline Family: Chrysopidae (green lacewings) & 0 & 0 & 0 & 1 & 1 \\
\hline Total insects & 41 & 31 & 324 & 415 & 809 \\
\hline Total orders & 4 & 4 & 5 & 6 & 6 \\
\hline Total families & 4 & 5 & 9 & 12 & 16 \\
\hline $\begin{array}{l}\text { Proportion of total insects from order } \\
\text { Orthoptera and Coleoptera }(\%)\end{array}$ & 12.2 & 22.6 & 86 & 96.1 & 85 \\
\hline
\end{tabular}

A Kruskal Wallis one-way ANOVA and Tukeys post hoc test $(\mathrm{p}<0.05)$ were used to determine differences in collection rates between all sites and percent of plant coverage after the values were angularly transformed (Zar 1999). Because diversity indices and evenness could only be calculated for the EB green roof and the RG, a student t-test was used to assess 
differences $(\mathrm{p}<0.05)$ between them. Due to our strict green roof selection criteria (close proximity, similarity in height and adjacent green space), we collected from only a few green roofs, which did not offer sufficient statistical power to generalize beyond the specific systems studied with correlation statistics as done in other studies (Zar, 1999; Schindler et al, 2011).

\section{RESULTS}

A total of 809 insects were collected from six orders and 16 families (Table 2). Over $92 \%$ of all the insects were collected from two locations, the EB green roof and the ground level RG, and $85 \%$ of those were from the orders of Orthoptera and Coleoptera (Table 2). From those that were identified to species, the cricket (Archeta domesticus) and ground beetles Harpalus pennsylvanicus and Chlaenius platyderus were most abundant, representing $81.5 \%$ of the 688 animals from the orders Orthoptera and Coleoptera (Table 3). The RG contained at least one specimen of each of the 14 identified species, while the SSC and RH only contained Melanoplus femorrubrom and A. domesticus, respectively (Table 3).

Percent plant coverage varied between all collection areas and was lowest in the ground level RG ( $42 \pm 0.05 \%$; Fig. 1), even though that plot had the highest total number of insects collected. Green roofs on the SSC and EB had coverage percentages in the mid to upper sixties, while the plot on RH was in the mid-fifties ( $55 \pm 0.04 \%$; Fig. 1).

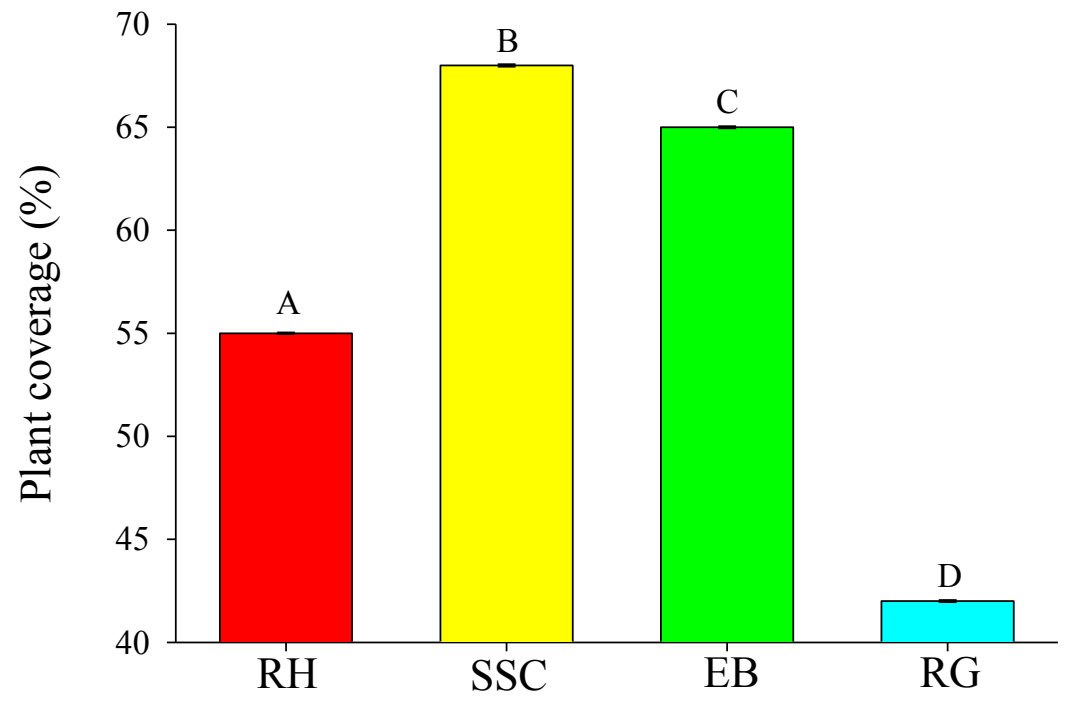

Collection area

Figure 1. Mean \pm SEM for plant coverage on green roofs located on Rendlemen Hall (RH), the Student Success Center (SSC) and the Engineering Building (EB) and a ground level rain garden $(\mathrm{RG})$. Standard errors that are not visible fall within the width of the top of the bar. Means that do not share a letter are significantly different when compared using Kruskal-Wallis one-way ANOVA on Ranks with a Tukey's post hoc test $(\mathrm{p}<0.05)$. 
Table 3. Total species of insects within the order Orthoptera and Coleopteran collected on green roofs located on Rendlemen Hall (RH), the Student Success Center (SSC) and the Engineering Building (EB). For comparative purposes, insects were also collected in a ground level rain garden (RG) located in close proximity to the EB. All insects were collected using pitfall traps from August $13^{\text {th }}$ to October $1^{\text {st }} 2010$.

\begin{tabular}{|c|c|c|c|c|c|}
\hline & $\mathrm{RH}$ & $\mathrm{SSC}$ & EB & $\mathrm{RG}$ & Total \\
\hline \multicolumn{6}{|l|}{ Order: Orthoptera } \\
\hline \multicolumn{6}{|l|}{ Family: Gryllidae } \\
\hline Archeta domesticus & 5 & 0 & 208 & 64 & 277 \\
\hline Allonemobius allardi & 0 & 0 & 43 & 12 & 55 \\
\hline Gryllus pennsylvanicus & 0 & 0 & 6 & 27 & 33 \\
\hline \multicolumn{6}{|l|}{ Family: Tetrigdae } \\
\hline Nomotettix cristatus & 0 & 0 & 0 & 2 & 2 \\
\hline Tetrix ornata & 0 & 0 & 0 & 1 & 1 \\
\hline \multicolumn{6}{|l|}{ Family: Acrididae } \\
\hline Melanoplus femurrubrum & 0 & 7 & 1 & 2 & 10 \\
\hline Dissosteria carolina & 0 & 0 & 0 & 6 & 6 \\
\hline \multicolumn{6}{|l|}{ Order: Coleoptera } \\
\hline \multicolumn{6}{|l|}{ Family: Carabidae } \\
\hline Harpalus pennsylvanicus & 0 & 0 & 18 & 106 & 124 \\
\hline Chlaenius platyderus & 0 & 0 & 1 & 159 & 160 \\
\hline \multicolumn{6}{|l|}{ Family: Scarabaediae } \\
\hline Strigoderma arbicola & 0 & 0 & 1 & 9 & 10 \\
\hline Copris fricator & 0 & 0 & 0 & 7 & 7 \\
\hline Xyloryctes jamaicensis & 0 & 0 & 0 & 1 & 1 \\
\hline Euphora inda & 0 & 0 & 0 & 1 & 1 \\
\hline \multicolumn{6}{|l|}{ Family: Lampyridae } \\
\hline Photinus pyralis & 0 & 0 & 0 & 1 & 1 \\
\hline Total insects & 5 & 7 & 278 & 399 & 688 \\
\hline Total families & 1 & 1 & 5 & 6 & 6 \\
\hline Total species & 1 & 1 & 7 & 14 & 14 \\
\hline
\end{tabular}




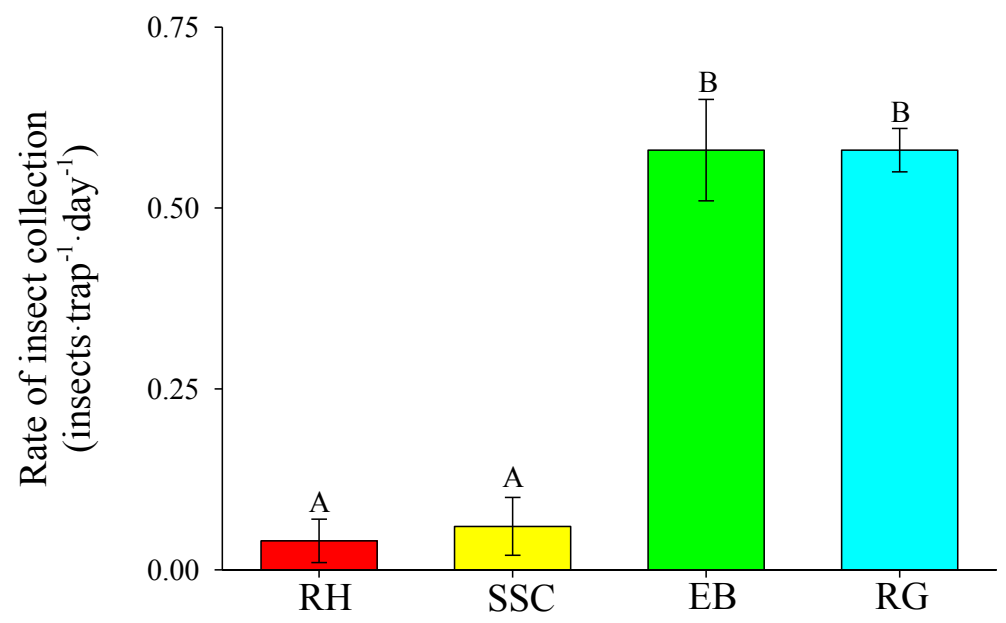

Collection area

Figure 2. Rate of insect collection (insects $\cdot \operatorname{trap}^{-1} \cdot$ day $^{-1}$ ) for green roofs on Rendelman Hall (RH), the Student Success Center (SSC), and the Engineering Building (EB) and the ground level rain garden $(\mathrm{RG})$. Insects were collected using pitfall traps from August $13^{\text {th }}$ to October $1^{\text {st }} 2010$. Means ( \pm SEM) not sharing a letter are significantly different when compared using Kruskal-Wallis one-way ANOVA on Ranks with a Tukeys post hoc test $(\mathrm{p}<0.05)$.

Similar to the total number of insects collected, rates of insect collection were highest for the green roof on the EB and the RG; both locations averaged 0.59 insects $\cdot \operatorname{trap}^{-1} \cdot$ day $^{-1}$ (Fig. 2). By contrast, trap effort was considerably lower on the green roofs located on RH and the SSC, which averaged only $0.07 \pm 0.04$ insects $\cdot \operatorname{trap}^{-1} \cdot$ day $^{-1}$. Even though collection rates were the same between the green roof on the EB and the RG, measures of species diversity and evenness were $139 \%$ and $41 \%$ higher in the $R G$, which averaged $1.41 \pm 0.07$ and $0.75 \pm 0.04$ respectively (Fig. $3 \mathrm{~A}$ and $\mathrm{B}$ ).

\section{DISCUSSION}

\section{Factors that may have Influenced Green Roof Insect Fauna Number and Diversity}

Our data indicate there is a substantial difference in number of and species diversity in insects between three green roofs at Southern Illinois University Edwardsville even though they are in close proximity, similar in distance to the nearest ground-level green space, and similar in initial species planted. The green roof on the EB had rates of insect collection that were over 8fold greater than rates for the green roofs on RH or the SSC (Fig. 1) and was the only roof that indices of species diversity (H') and evenness $(\mathrm{J})$ using Orthopterans and Coleopterans could be calculated. 


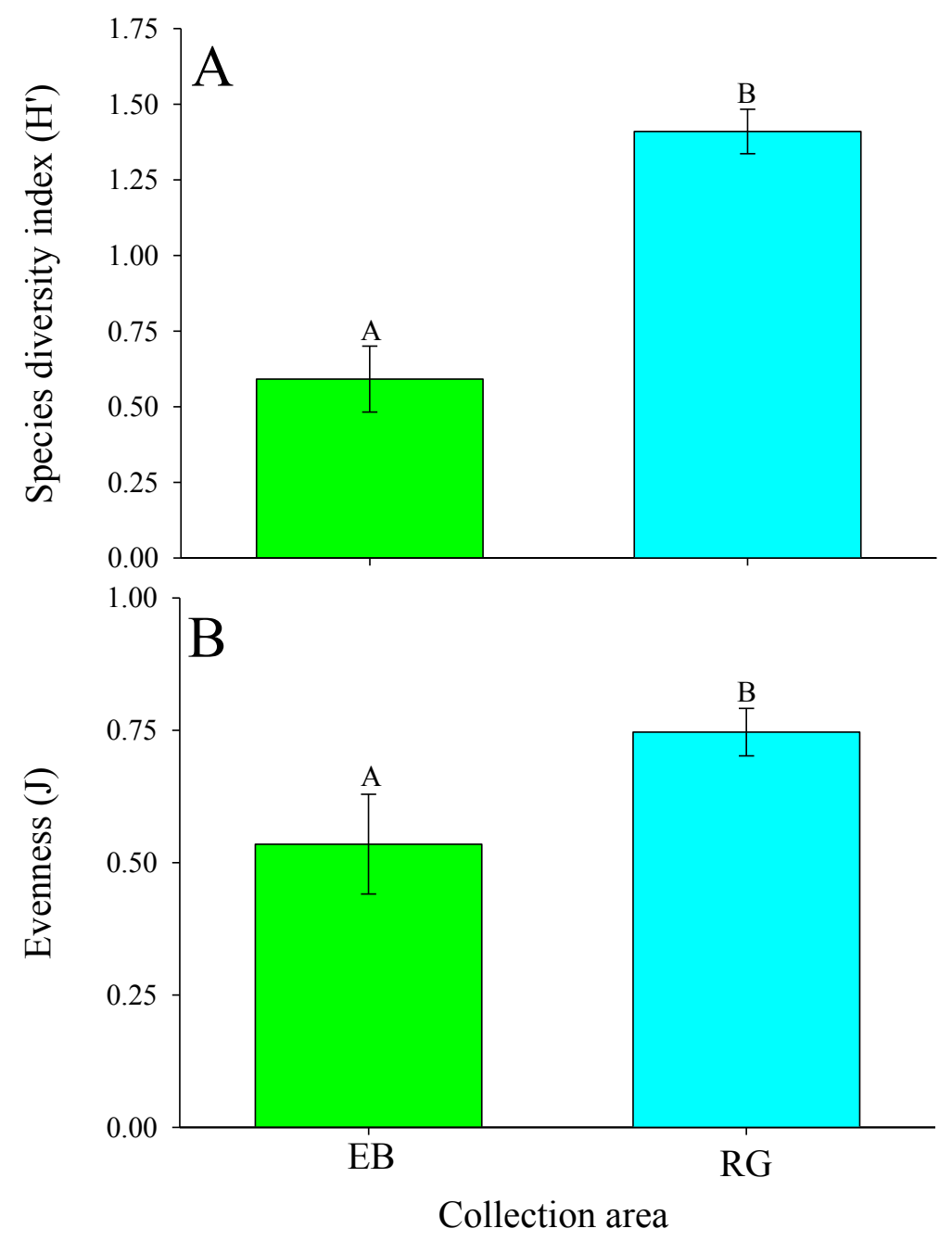

Figure 3. (A) Species diversity index (H') and (B) evenness (J) for the green roof on the Engineering Building (EB) and the ground level rain garden (RG) located on the campus of Southern Illinois University Edwardsville. Species of Orthopteran and Coleopteran insects used to generate this data were collected using pitfall traps from August $13^{\text {th }}$ to October $1^{\text {st }}$ 2010. Means $( \pm \mathrm{SEM})$ not sharing a letter are significantly different when compared using a student's T-test $(\mathrm{p}<0.05)$. Only one species from the orders Orthoptera or Coleoptera were collected from the Rendleman Hall and the Student Success Center green roofs and, thus, were omitted from this figure.

Factors that were dissimilar between the three green roofs that may have led to different rates of insect collection include roof area, percentage of plant coverage and/or age (Table 1). The green roof on the EB had the highest rate of insect collection even though it was intermediate in size (Table 1) and plant coverage (Fig. 1). Such results parallel previous work indicating green roof area had little effect on insect species diversity (Gedge and Kadas 2005; Schindler et al. 2011) but differ to data from Schindler et al. (2011) that positively linked insect diversity with percentage of ground cover by plants. In contrast to roof area and percent plant coverage, time since establishment was the greatest for the green roof on the EB, which may 
have contributed to its high rates of insect collection. Schrader and Böning (2006) did in fact correlate green roof age with greater niche occupancy for collembolans, a non-insect soil dwelling arthropod, suggesting roof age is important. Nevertheless, due to the fact that only three green roofs were sampled in this study, it would be inappropriate to link roof features to collection rates from our data. However, our data indicate that time since establishment does merit future study when examining insect diversity on green roofs.

\section{Insect communities on the green roofs largely resembled ground level communities}

Even though rates of insect collection were similar between the green roof on the EB and the RG, species diversity and evenness were considerably higher in the ground level RG. Considering plant coverage was lower in the RG (Fig. 1) and the RG was established much more recently than the EB green roof (Table 1), the higher levels of species diversity and evenness in the RG could have been the result of being contiguous with the surrounding green space. In addition, the higher plant diversity in the RG may have also played a role, however this is speculation.

Evaluations of the relationship between green roof faunal communities to that of ground level fauna have been mixed. Gedge and Kadas (2005) indicated unique invertebrate communities existed on the green roofs they examined while studies by MacIvor and Lundholm (2011) and Tonietto et al. (2011) suggest green roof invertebrate fauna were similar in structure to ground level habitats but had fewer species. We also had mixed results in the current study. For instance, almost all families of insects, especially those in the family Orthoptera and Coleoptera, collected on green roofs were also found at grade (Table 2 and 3). Likewise, several species, families, and even an order that was collected in the RG were not found on any of the green roofs, indicating that the bulk of the insect community on green roofs were a limited representative sample of the surrounding ground level community. However, there were a few unique families in the order Hemiptera, specifically Lygaidae and Nabidae, that were represented more frequently on green roofs than at grade (Table 2). Hemipterans in the family Lygaidae are phytophagus true bugs that may have been attracted to the green roofs due to a specific plant or plants that were absent in the RG (Borror et al. 1989). Also, members of the family Nabidae are predacious and feed on other insects, including aphids and caterpillars (Borror et al. 1989). Thus, members of this family were likely attracted to the green roofs due to insect prey already present on the roofs. Regardless of the reason for their collection, the fact that these insects were found in greater numbers on green roofs suggest that unique insect communities could exist on green roofs.

In summary, even though the green roofs examined in this study were close in proximity, similar in distance to the nearest ground level green space, and similar in plant species diversity, collection rates differed between them. In addition, the bulk of insects collected on green roofs resembled ground level communities, but with less diversity. However, there were a few insects that were found only on green roofs, indicating that green roofs could contain unique communities compared to the surrounding ground level green space. 


\section{ACKNOWLEDGMENTS}

We thank Green Roof Blocks (Mr. Kelly Luckett) and Jost Greenhouses (Mr. Vic Jost) for providing the green roof materials and plants. We also thank the SIUe Vice-Chancellor for Administration, Dr. Kenn Neher, for providing funds for creation of the rain garden.

\section{LITERATURE CITED}

Arnett, R. H. and M. C. Thomas. 2000. American Beetles, Volume 1: Archostemata, Myxophaga, Adephaga, Polyphaga: Staphyliniformia. Boca Raton, FL: CRC Press.

Arnett, R. H., M. C. Thomas, P. E. Skelley, and J. H. Frank. 2002. American Beetles, Volume II: Polyphaga: Scarabaeoidea through Curculionoidea. Boca Raton, FL: CRC Press.

Bland, R. G. 2003. The Orthoptera of Michigan: Biology, Keys, and Descriptionsof Grasshoppers, Katydids, and Crickets. East Lansing, MI: Michigan State University Extension.

Bland, R. G. and H. E. Jaques. 1978. How to Know the Insects, Third Edition. Long Grove, IL: Waveland Press, Inc.

Borror, D. J., C. A. Triplehorn, and N. F. Johnson. 1989. Introduction to the Study of Insects. 6th edition ed. Philadelphia: Saunders College Publishing.

Brenneisen, S. 2003. "The Benefits of Biodiversity from Green Roofs - Key Design Consequences." Proceedings of 1st North American Green Roof Conference: Greening rooftops for sustainable communities. Chicago, Illinois. 29-30.

Clark, W.H. and P.E. Blom. 1992. An efficient and inexpensive pitfall trap system. Entomol. News 103: 55-59.

Dewey, D., P. Johnson, and R. Kjelgren. 2004. "Species Composition Changes in a Rooftop Grass and Wildlife Meadow." Native Plants 5: 56-65.

Epstein, M. E. and H. M. Kulman. 1990. "Habitat Distribution and Seasonal Occurrence of Carabid Beetles in East-Central Minnesota." American Midland Naturalist 123 (2): 209-225.

Forrester, K. 2006. "Evaluation of Storm Water Runoff from a Midwestern Green Roof System." Thesis, Southern Illinois University Edwardsville.

Gedge, D. and G. Kadas. 2005. "Green Roofs For Biodiversity - Designing Green Roofs to Meet Targets of BAP (Biodiversity Action Plan) Species." World Green Roof Congress Conference Transcript. Basel, Switzerland. 177-184.

Getter, K. L. and D. B. Rowe. 2006. "The Role of Extensive Green Roofs in Sustainable Development." Hortscience 41 (5): 1276-1285.

Grant, G. 2006. "Extensive Green Roofs in London." Urban Habitats 4 (1): 51-65.

Jackson, L. E. 2003. "The Relationship of Urban Design to Human Health and Condition." Landscape and Urban Planning 64 (4): 191-200.

Jo, H. K. 2002. "Impacts of Urban Greenspace on Offsetting Carbon Emissions for Middle Korea." Journal of Environmental Management 64 (2): 115-126.

Kadas, G. 2006. "Rare Invertebrates Colonizing Green Roofs in London." Urban Habitats 4 (1): 66-86.

Krebs, C. J. 1989. Ecological Methodology. New York, NY: Harper Collins.

MacIvor, J. S. and J. Lundholm. 2011. "Insect Species Composition and Diversity on Intensive Green Roofs and Adjacent Level-Ground Habitats." Urban Ecosystems 14 (2): 225-241.

Madre, F., Vergnes, A., Machon, N., and P. Clergeau. 2013. "A Comparison of 3 Types of Green Roofs as Habitat for Athropods.” Ecological Engineering 57: 109-117.

Schindler, B. Y., A. B. Griffith, and K. N. Jones. 2011. "Factors Influencing Arthropod Diversity on Green Roofs." Cities and the Environment 4 (1): 1-20.

Schrader, S., and M. Böning. 2006. "Soil Formation on Green Roofs and its Contribution to Urban Biodiversity with Emphasis on Collembolans.” Pedobiologia 50: 347-356. 
Susca, T., S. R. Gaffin, and G. R. Dell'Osso. 2011. "Positive Effects of Vegetation: Urban Heat Island and Green Roofs." Environmental Pollution 159 (8-9): 2119-2126.

Sutton, R. K. 2014. "Aesthetics for Green Roofs and Green Walls.” Journal of Living Architecture (2): 120.

Tonietto, R., J. Fant, J. Ascher, K. Ellis, and D. Larkin. 2011. "A Comparison of Bee Communities of Chicago Green Roofs, Parks and Prairies." Landscape and Urban Planning 103 (1): 102-108.

Yang, H. S., J. Kang, and M. S. Choi. 2012. "Acoustic Effects of Green Roof Systems on a Low-Profiled Structure at Street Level." Building and Environment 50: 44-55.

Zar, J. H. 1999. Biostatistical Analysis. 4th Edition . Upper Saddle River, NJ: Prentice Hall. 